This paper was published as follows:

Camilleri,S.J. (2015) "Do call auctions curtail price volatility? Evidence from the National Stock Exchange of India", Managerial Finance, 41 (1), pp. 67 - 79.

Publication may be accessed at:

http://dx.doi.org/10.1108/MF-10-2013-0292

\title{
Do Call Auctions Curtail Price Volatility? EVIDENCE FROM THE NATIONAL STOCK EXCHANGE OF INDIA
}

\author{
Silvio John Camilleri \\ Banking and Finance Dept., FEMA, University of Malta. \\ silvio.j.camilleri@um.edu.mt
}


This article is (C) Emerald Group Publishing and permission has been granted for this version to appear on www.um.edu.mt. Emerald does not grant permission for this article to be further copied/distributed or hosted elsewhere without the express permission from Emerald Group Publishing Limited.

Camilleri,S.J. (2015) "Do call auctions curtail price volatility? Evidence from the National Stock Exchange of India", Managerial Finance, 41 (1), pp. 67 - 79.

\section{ABSTRACT}

\section{Purpose}

This paper empirically investigates whether call auctions which batch orders for simultaneous execution, may restrain stock market volatility.

\section{Design / Methodology / Approach}

We use high frequency data to investigate volatility changes following the suspension of opening and closing call auctions on the National Stock Exchange of India in June 1999. We evaluate this issue by considering both modelled and realised volatility. Using a GARCH approach we model intra-day volatility for the trading days preceding and succeeding the auction suspension. We also scrutinise return distributions to look for volatility changes during different parts of the day.

\section{Findings}

When interpreted collectively, our empirical results suggest that the auction suspension was followed by reduced volatility particularly in the middle of the trading day and at the closing.

\section{Practical implications}

Given that auctions are often incorporated in trading systems with the aim of curtailing volatility, our main conclusion, that the auction suspension was followed by lower volatility, has important practical inferences. Auctions cannot be automatically relied on to reduce volatility. The intricacies of the auction protocol and their interaction with ancillary market microstructure features may impact on auction efficacy.

\section{Originality / value}

The paper adopts a novel approach towards assessing the effectiveness of call auctions by considering an unusual occurrence of an auction suspension. The empirical setting enables a clear comparison of the respective regimes since the auction and the post-suspension period do not materially differ in other subsidiary aspects. This is a noteworthy factor, since the empirical contexts considered in prior studies, often feature several simultaneous changes.

Keywords: Call Auctions, National Stock Exchange of India, Stock Markets, Volatility JEL Classification: G12, G18 
This article is @ Emerald Group Publishing and permission has been granted for this version to appear on www.um.edu.mt. Emerald does not grant permission for this article to be further copied/distributed or hosted elsewhere without the express permission from Emerald Group Publishing Limited.

Camilleri,S.J. (2015) "Do call auctions curtail price volatility? Evidence from the National Stock Exchange of India", Managerial Finance, 41 (1), pp. 67 - 79.

1.

\section{Introduction}

In this paper we evaluate the impact of an unusual empirical market microstructure occurrence, namely: the suspension of opening and closing call auctions by the National Stock Exchange of India (NSE) on the 9th June 1999. The main impetus for this study is the research by Camilleri and Green (2009) which yielded contrasting, although highly significant results in terms of volatility changes around this auction suspension. A study of the auction suspension by the NSE presents the noteworthy advantage that it involves a comparison between two regimes which differ only in terms of the presence of the auction. This enables a relatively clear assessment of the impact of the suspension, given that other market features on the exchange remained unchanged.

One main objective in designing trading protocols is to curtail excess volatility. This helps to enhance price discovery by minimizing market movements which push prices away from fundamental values. The efficacy of call auctions in promoting this objective, as compared to continuous trading, is one important issue in the design of trading protocols. In a call auction, orders are batched together and executed simultaneously at a common price at a given point in time. By contrast, in a continuous system, trading may occur at any instant when two orders on the opposite side of the market meet in price. In theory, call auctions provide an efficient mechanism for aggregating diverse information because trading does not take place until price discovery has occurred. In continuous systems, price discovery and trading take place simultaneously implying that trades may occur at "false" prices (Schwartz, 2000).

If call auctions reduce fluctuations around the fundamental values of securities, this should result in lower volatility during the trading day. It is therefore important to 
This article is (C) Emerald Group Publishing and permission has been granted for this version to appear on www.um.edu.mt. Emerald does not grant permission for this article to be further copied/distributed or hosted elsewhere without the express permission from Emerald Group Publishing Limited.

Camilleri,S.J. (2015) "Do call auctions curtail price volatility? Evidence from the National Stock Exchange of India", Managerial Finance, 41 (1), pp. 67 - 79.

assess intra-day volatility when considering auction effectiveness. Despite this, the issue of whether call auctions do actually restrain volatility is still unresolved and different studies yield contrasting results. The fact that call auctions may vary in structure makes it difficult to carry out clear-cut comparisons between auctions and continuous trading.

With reference to the empirical context considered in this paper, Camilleri and Green (2009) reported that, following the 1999 auction suspension by the NSE, there was a highly significant drop in intra-day volatility but also significantly higher tendencies for reversals of overnight returns. We delve deeper into this puzzle by applying various tests on data which are sampled at higher frequencies than those used in the previous studies.

We use GARCH models and scrutinise return distributions to evaluate the changes in intra-day volatility following the auction suspension. This is an important aspect of this study since, by focusing on both realised and modelled volatility, one may expect to obtain richer insights (Zhang and $\mathrm{Hu}$; 2013).

The rest of the paper is structured as follows. Section 2 includes a review of relevant literature, while section 3 describes the empirical context and the data. In section 4, we investigate the impact of the auction suspension through GARCH models. In section 5, we undertake a comparison of return distributions as between the auction period and the post-suspension period. Section 6 concludes.

\section{Review of Literature}

There are two trading frameworks which commonly feature in order-driven systems: call auctions and continuous trading. The latter systems may be combined in a 
This article is (C) Emerald Group Publishing and permission has been granted for this version to appear on www.um.edu.mt. Emerald does not grant permission for this article to be further copied/distributed or hosted elsewhere without the express permission from Emerald Group Publishing Limited.

Camilleri,S.J. (2015) "Do call auctions curtail price volatility? Evidence from the National Stock Exchange of India", Managerial Finance, 41 (1), pp. 67 - 79.

hybrid trading setup, such as an auction held at the start and at the close of the day, with continous trading in between. Call auction protocols vary and therefore auctions may have different impacts on trading activity (Comerton-Forde and Rydge, 2006). This partly explains the mixed evidence on call auction efficacy described in this section. Furthermore, ancillary operational features differ across markets and therefore even similarly-structured auctions may have different implications in different contexts.

The potential for auctions to curtail volatility mainly rests on the expectation that they increase pricing efficiency, and thus one may deduce that they reduce the dispersion of prices around their fundamental values. Economides and Schwartz (1995) argued that call auctions aggregate different expectations of market participants thereby increasing price discovery and pricing efficiency. Schwartz (2000) contrasted the notion of a call auction market where trades are executed after price discovery occurs, with the operation of a continuous market where prices are discovered whilst trading occurs. Madhavan (1992) theoretically investigated the performance of different market structures and concluded that auctions aggregate information more efficiently, especially when the level of asymmetric information in the market is high, and dealers are reluctant to take the opposite sides of trades.

Despite this, the model proposed by Caillaud and Mezzetti (2004) indicates that there may be limitations in the extent to which call auctions can aggregate information efficiently. In particular, some market participants may use the auction setup to conceal information from other traders, such as giving up profitable trading opportunities in an initial auction, in the hope that the resulting price movements materialise in higher subsequent profits. 
This article is (C) Emerald Group Publishing and permission has been granted for this version to appear on www.um.edu.mt. Emerald does not grant permission for this article to be further copied/distributed or hosted elsewhere without the express permission from Emerald Group Publishing Limited.

Camilleri,S.J. (2015) "Do call auctions curtail price volatility? Evidence from the National Stock Exchange of India", Managerial Finance, 41 (1), pp. 67 - 79.

One central issue in the debate between call auctions and continuous trading is the trade-off between information efficiency and immediacy. In particular, periodic auctions lack continuity and therefore reduce the immediacy of trading. In this way, they may also result in higher information costs given that current prices are available less frequently (Madhavan, 1992). However, the latter arguments are less relevant when call auctions are used at the opening or closing, since trading still occurs continuously for the rest of the day.

Various authors have empirically investigated the pricing efficiency of auctions as postulated by the above theoretical arguments. An investigation of the pre-open call auction of the (former) Paris Bourse by Biais, Hillion and Spatt (1999), suggests that price discovery reaches its peak in the last minutes of the auction, whereas orders posted during the initial minutes may be classified as "noise". This contrasts with other findings, for example, that most of the orders at the pre-opening period of the Toronto Stock Exchange (Davies, 2003) and the West-African Bourse (Dia and Pouget, 2011) are submitted with the intention of trading.

Chang et. al. (2008) considered the introduction of opening and closing call auctions on the Singapore Stock Exchange in the year 2000. They reported higher pricing efficiency and reduced volatility especially in the case of liquid stocks. ChelleySteeley (2008) studied the introduction of a closing call auction on the London Stock Exchange in 1997 and reported higher pricing efficiency, especially for the least active stocks. Frino, Gerace and Lepone (2008) considered the liquidity changes for the stocks trading on the Italian Bourse which in 2001 transitioned from an auction market to a specialist system. The authors noted a reduction in the price impact of trades and obtained indications that a specialist setup may be better equipped to handle the adverse selection risk related to informed trading. Madhavan and Panchapagesan (2000) analysed the opening auction on the New York Stock 
This article is (C) Emerald Group Publishing and permission has been granted for this version to appear on www.um.edu.mt. Emerald does not grant permission for this article to be further copied/distributed or hosted elsewhere without the express permission from Emerald Group Publishing Limited.

Camilleri,S.J. (2015) "Do call auctions curtail price volatility? Evidence from the National Stock Exchange of India", Managerial Finance, 41 (1), pp. 67 - 79.

Exchange (NYSE) and found that call auctions might not be the ideal trading setup for less liquid stocks, given that order imbalances may lead to mispricings.

Other studies have empirically compared auction price characteristics with those of the continuous trading session on a given market (Amihud and Mendelson, 1987; Shastri, Shastri and Sirodom, 1995). It was found that auction prices were more volatile; yet this might also be due to the fact that call auctions are most commonly held at the opening and/or closing of the session when volatility tends to be higher than during the rest of the day. The latter argument is corroborated by the empirical study of Ronen (1998) for the Tel-Aviv Stock Exchange: when the auction was moved from the closing to the opening in 1988, no significant differences in opening volatility were discerned.

Biais and Pouget (2000) set up experimental markets involving call auctions. They concluded that price discovery may be augmented by organising a pre-opening period prior to the auction without executing any trades. This disseminates a volumemaximising price based on the incoming orders.

Call auctions may impact on intra-day volatility in terms of their prospects for curtailing market manipulation. In the theoretical model of Hillion and Suominen (2004), and the empirical research of Chang et. al. (2008) focusing on the Singapore Stock Exchange, call auctions are successful in reducing the potential to manipulate closing prices. Similarly, Pinfold and He (2012) reported higher pricing efficiency and lower market manipulation potential following the introduction of an auction on the New Zealand stock market.

Comerton-Forde and Rydge (2006) considered two cases of manipulative orders: the first one for a liquid stock and the second one for an illiquid stock. The authors studied how auctions featuring different matching algorithms coped with manipulation 
This article is (C) Emerald Group Publishing and permission has been granted for this version to appear on www.um.edu.mt. Emerald does not grant permission for this article to be further copied/distributed or hosted elsewhere without the express permission from Emerald Group Publishing Limited.

Camilleri,S.J. (2015) "Do call auctions curtail price volatility? Evidence from the National Stock Exchange of India", Managerial Finance, 41 (1), pp. 67 - 79.

attempts. In case of the illiquid stock, trading took place in the presence of the manipulative order, yet no market clearing price could be established when this order was removed. This casts doubts on the notion that auctions are particularly suited to trade less liquid stocks. The authors argued that the auction algorithm on its own might be unable to restrain the effects of manipulative orders; and complementary features such as order restrictions and random auction termination time may thus be required.

Our empirical setting of the auction suspension on NSE in June 1999 was analysed by Camilleri and Green (2009) who focused on the changes in efficiency, liquidity and volatility. The authors obtained overall evidence that the auctions did not result in significant improvements in these factors. Their investigation found mixed evidence on the relationship between the auction setup and volatility. The price dispersion during the trading day decreased significantly following the suspension, implying lower intra-day volatility. Yet, the authors also reported significantly higher overnight volatility following suspension, given that reversals of overnight returns became more prominent.

When considered collectively, the above findings imply that the relationship between call auctions and volatility is still an unresolved issue; and therefore this empirical study offers a contribution towards filling this lacuna.

\section{Empirical Setting and Data}

The National Stock Exchange of India (NSE) was established in 1994 and is one of two major Indian exchanges. As at May 2013, around 1,600 equities traded on NSE and the volume on a typical day was over 5 million transactions. The NSE is an order-driven market, and offers particular advantages for a study of this kind, due to a 
This article is (C) Emerald Group Publishing and permission has been granted for this version to appear on www.um.edu.mt. Emerald does not grant permission for this article to be further copied/distributed or hosted elsewhere without the express permission from Emerald Group Publishing Limited.

Camilleri,S.J. (2015) "Do call auctions curtail price volatility? Evidence from the National Stock Exchange of India", Managerial Finance, 41 (1), pp. 67 - 79.

comprehensive number of traded equities and high trading volumes for the most liquid stocks.

The exchange introduced opening and closing call auctions in the late 1990s. The latter established prices for individual securities in a way to maximise the traded quantity. Orders could be modified or cancelled at any time. When auctions were in effect, the opening auction was held between 09:55 and 10:00, followed by continuous trading until around 15:30, and a final closing auction between 15:50 and 15:55. The opening and closing auctions were suspended without prior notice on $9^{\text {th }}$ June 1999. Camilleri and Green (2009) offer background information about these auctions and their suspension which could have been related to software problems. They report that trading activity tended to be higher in the closing auction as compared to the opening one.

This study uses NSE Nifty Index intra-day data. The Nifty is one of the main indices compiled by NSE, and is composed of 50 large-capitalisation stocks. In sampling the intra-day data, we started with the sixteen trading days immediately preceding suspension and the sixteen days following suspension. The first regime (auction period) consists of the trading days from $18^{\text {th }}$ May 1999 to $8^{\text {th }}$ June 1999 , while the second regime (suspension period) consists of trading days from $9^{\text {th }}$ June 1999 until $30^{\text {th }}$ June 1999. Two days which were interrupted by trading halts were discarded $\left(21^{\text {st }}\right.$ May and $28^{\text {th }}$ June 1999$)$, and the final sample thus consisted of fifteen trading days in each regime.

Intra-day observations typically started at 10:00 and ended at 15:29 yielding a total of 330 observations at one minute intervals for each trading day. In case of the auction period, more observations were available owing to the additional trading time. The twenty-minute trading gap, between the continuous trading session and the closing 
This article is (C) Emerald Group Publishing and permission has been granted for this version to appear on www.um.edu.mt. Emerald does not grant permission for this article to be further copied/distributed or hosted elsewhere without the express permission from Emerald Group Publishing Limited.

Camilleri,S.J. (2015) "Do call auctions curtail price volatility? Evidence from the National Stock Exchange of India", Managerial Finance, 41 (1), pp. 67 - 79.

auction was treated as a regular one-minute interval, since these returns were typically in a similar range to that of the regular one-minute returns. First-Order Augmented Dickey-Fuller tests rejected the null hypothesis of a unit root at the $95 \%$ confidence level for all log return data.

\section{4.}

\section{GARCH Models}

In this section we estimate GARCH models using the Nifty Index observations sampled at one-minute frequency to assess whether the auction suspension led to any changes in intra-day volatility. We estimate a different GARCH model for each of the fifteen sampled auction days; and these are compared to a set of estimated GARCH models for the fifteen post-suspension days. We used the Akaike Information Criterion and the Schwarz Bayesian Criterion to select the standard return generating process for the available time series, which comprise the intra-day observations of the 30 sampled trading days. The criteria selected an $A R(1)$ model for over half of the data sets. An $A R(1)$ was therefore adopted as the standard return generation process for each GARCH model which was estimated using the time series for the particular day.

LM heteroskedasticity tests (Engle; 1982) rejected the Null Hypothesis of no ARCH effects at the $95 \%$ level of confidence for around $50 \%$ of the data sets. Tests on the degree of asymmetry in conditional volatility indicated that it was not necessary to account for this feature. [1]

We now proceed with the estimation of the GARCH models. In line with Andersen and Bollerslev (1997) we chose a GARCH $(1,1)$ specification since this usually provides acceptable estimates: 
This article is @ Emerald Group Publishing and permission has been granted for this version to appear on www.um.edu.mt. Emerald does not grant permission for this article to be further copied/distributed or hosted elsewhere without the express permission from Emerald Group Publishing Limited.

Camilleri,S.J. (2015) "Do call auctions curtail price volatility? Evidence from the National Stock Exchange of India", Managerial Finance, 41 (1), pp. 67 - 79.

$$
h_{t}=\omega+\alpha \varepsilon_{t-1}^{2}+\beta h_{t-1}
$$

where $h_{t}$ denotes the conditional variance which depends on past information, $\varepsilon_{t}^{2}$ is the unexpected squared return observed during period $t$, and $\omega, \alpha, \beta$ are parameters. [2]

In order to obtain estimates which more accurately model intra-day volatility, and to maximise the chances of obtaining estimates for each sampled trading day, we estimated two different GARCH models on the one-minute observations of the Nifty Index. The first model assumed that the conditional distribution of the errors was normal whilst the second model assumed that it followed a student-t distribution. In the former case, three out of thirty estimates failed to converge, whilst in the latter case, ten estimates did not converge. This suggests that the volatility patterns which transpired during the latter trading days, were somewhat dissimilar from the characteristics which are usually captured through $\mathrm{GARCH}$ models. A number of estimates were omitted due to any one of the following features:

a) A Wald Test failed to reject the Null Hypothesis that $(\alpha+\beta)=1$, since this violates the required stationarity condition of $\mathrm{GARCH}$ models.

b) The estimated coefficient for the lagged conditional variance was negative and highly significant since such an estimate does not make sense (Engle; 2001).

c) The $R^{2}$ statistic was negative indicating very poor explanatory power.

Following these omissions, we used the Akaike Information Criterion to select the preferred model for each trading day: the normal distribution model or the $\mathrm{t}$ distribution in those cases where both were still available. This resulted in 23 $\mathrm{GARCH}$ models available for analysis, each replicating the characteristics of the 
This article is (C) Emerald Group Publishing and permission has been granted for this version to appear on www.um.edu.mt. Emerald does not grant permission for this article to be further copied/distributed or hosted elsewhere without the express permission from Emerald Group Publishing Limited.

Camilleri,S.J. (2015) "Do call auctions curtail price volatility? Evidence from the National Stock Exchange of India", Managerial Finance, 41 (1), pp. 67 - 79.

volatility of the NIFTY Index observations sampled at one-minute intervals for the respective trading day. Thirteen of these models relate to trading days from the auction period whilst ten estimates model trading days from the suspension period (Tables 1 and 2).

The GARCH $(1,1)$ estimates show that the $A R(1)$ coefficient of the return equation is significant. Despite that this is inconsistent with weak-form efficiency (Fama, 1970), some degree of serial dependence may be expected in high-frequency data, where returns are affected by factors such as non-synchronous trading and the bid-ask bounce. As regards the conditional variance equation, most of the $\alpha$ and $\beta$ are significant, and Wald tests reject the null hypothesis that $\alpha+\beta=0$. We thus infer that lagged errors and shocks have a significant effect on conditional volatility.

Tables 1 and 2 about here

We now turn to the interpretation of the GARCH coefficients. According to Franses and Van Dijk (2000), the unconditional mean of $\varepsilon_{t}^{2}$ or the unconditional variance of $\varepsilon_{t}$ is equal to:

$$
\sigma^{2}=\frac{\omega}{1-\alpha-\beta}
$$

Volatility is expected to converge to this value over the long-term. $\alpha$ and $\beta$ are the ARMA components of the conditional variance i.e. the unexpected lagged squared return and the lagged conditional variance. These may be interpreted as temporary deviations around the unconditional variance which depend on past information. 
This article is (C) Emerald Group Publishing and permission has been granted for this version to appear on www.um.edu.mt. Emerald does not grant permission for this article to be further copied/distributed or hosted elsewhere without the express permission from Emerald Group Publishing Limited.

Camilleri,S.J. (2015) "Do call auctions curtail price volatility? Evidence from the National Stock Exchange of India", Managerial Finance, 41 (1), pp. 67 - 79.

Most of these coefficients, especially those relating to $\beta$, are significant and we may thus conclude that there is a substantial degree of persistence in the Nifty index.

Table 3 shows the results of t-tests on the GARCH model coefficients to examine any differences between the auction period and the suspension period. The reduction in $\alpha$ was significant at the $90 \%$ level of confidence, yet this did not lead to any significant difference in the combined GARCH coefficients $(\alpha+\beta)$. Still, the results indicate an overall highly significant drop in the unconditional variance of $\varepsilon_{t}$ as shown in the last column.

Table 3 about here

5. Scrutinising Return Distributions

In the case of high-frequency data, realized volatility may prove to be a superior measure than modelled volatility (Dacorogna, et. al., 2001, pp. 44) and in addition one may expect to garner richer insights when using both approaches (Zhang and $\mathrm{Hu}, 2013)$. We thus consider changes in the intra-day realised return distributions, and test whether the initial volatility consists of over-reactions or noise.

For each of the 30 sampled trading days, we first split the one-minute returns into opening (comprising the first 40 observations), closing (comprising the final 40 observations) and middle of the day (remaining observations). In testing for the differences in volatility during these sections of the day, we used two volatility proxies: the Mean Squared Returns and the Return Standard Deviations for the particular intra-day period. Two-tailed paired sample t-tests (Table 4) rejected the hypotheses of no difference between the returns across the trading day at the $95 \%$ 
This article is (C) Emerald Group Publishing and permission has been granted for this version to appear on www.um.edu.mt. Emerald does not grant permission for this article to be further copied/distributed or hosted elsewhere without the express permission from Emerald Group Publishing Limited.

Camilleri,S.J. (2015) "Do call auctions curtail price volatility? Evidence from the National Stock Exchange of India", Managerial Finance, 41 (1), pp. 67 - 79.

level of confidence, confirming that volatility reached its peak at the opening phase and then rose again towards the end.

Tables 4 and 5 about here

We now consider the differences between the auction and the suspension period across the different sections of the trading days. The statistics for the opening distributions (Table 5) indicate an increase in opening volatility following suspension. This is in contrast to the middle-of-the-day and the closing distributions which suggest lower volatility following suspension. As regards the kurtosis for the whole 30 days, the opening returns tend to be the most peak-shaped, hinting that whilst the opening is more volatile, it is also characterised by a number of returns which are close to zero. Log return plots confirm that the opening is characterised by a large return taking place within the first fifteen minutes, followed by smaller returns. Such patterns suggest that prices initially fluctuate in response to overnight news, and subsequent movements depend on temporary liquidity features. If the large return is not subsequently reversed, this suggests that most of the initial price discovery occurs within one or two minutes. However, if the large return is then reversed or partially reversed, this might imply that the initial volatility is more nearly noise or over-reaction.

We therefore start by distinguishing between reinforcements and reversals of initial returns. When the direction of the return for the first fifteen minutes is the same as that of the return for the rest of the day, the sequence is classified as a reinforcement. When the initial fifteen-minute return changes direction during the rest of the day, the sequence is classified as a reversal. A note on possible limitations of this methodology is warranted. The test may be biased in favour of 
This article is (C) Emerald Group Publishing and permission has been granted for this version to appear on www.um.edu.mt. Emerald does not grant permission for this article to be further copied/distributed or hosted elsewhere without the express permission from Emerald Group Publishing Limited.

Camilleri,S.J. (2015) "Do call auctions curtail price volatility? Evidence from the National Stock Exchange of India", Managerial Finance, 41 (1), pp. 67 - 79.

reinforcements, due to market factors such as larger orders executing in smaller components (Madhavan, Richardson and Roomans, 1997) and non-synchronous trading (Camilleri and Green, 2014). In addition, the underlying news pattern (which is not observed) may in fact justify some instances of reversal. Yet, it may be expected that over a 30 day sample this methodology yields reasonably reliable results.

Results shown in Table 6 indicate that reversals are more prominent than reinforcements.[3] The fact that reversals are more evident in the auction period suggests that the higher initial volatility in the suspension period (Table 5) should be interpreted with caution, since there seemes to be a higher probabilty that the larger price movements of the suspension period were in fact justified. This evidence is in line with the findings of Camilleri and Green (2009) that the NSE auction suspension was followed by higher efficiency and lower intra-day volatility. The latter study focussed on a longer 120-trading day period, and therefore provides some reassurance that the new intra-day results reported in this paper are not samplespecific.

Table 6 about here

6. Conclusion

We evaluated the changes in intra-day volatility following the suspension of opening and closing call auctions on the NSE. GARCH models estimated on intra-day data point at a significant drop in the response of the conditional variance to lagged shocks, as well as a highly significant drop in the unconditional variance following the 
This article is (C) Emerald Group Publishing and permission has been granted for this version to appear on www.um.edu.mt. Emerald does not grant permission for this article to be further copied/distributed or hosted elsewhere without the express permission from Emerald Group Publishing Limited.

Camilleri,S.J. (2015) "Do call auctions curtail price volatility? Evidence from the National Stock Exchange of India", Managerial Finance, 41 (1), pp. 67 - 79.

suspension. We also considered one-minute return distributions and found that the suspension period is characterised by lower volatility in the middle-of-the-day and the closing. The opening volatility increased following the suspension, yet the auction period is characterised by higher incidence of reversals of opening returns suggesting that there is a higher possibility of unjustified opening volatility during the auction period. Collectively these results cast doubt on whether any expected benefits of call auctions were in fact materialising, since NSE witnessed an overall drop in intra-day volatility following the auction suspension. When compared to the prior mixed findings of Camilleri and Green (2009), the above results offer a more detailed assessment and contribute towards a clearer insight of the volatility changes, which took place following the NSE auction suspension.

The above evidence might not serve as a case for the universal suspension of call auctions; yet it is useful from the point of view of market designers who should not rely on auctions as a carte blanche for lower volatility and higher efficiency. Thought has to be given to the actual design of auctions, as auctions can be used to mislead traders (Biais, Hillion and Spatt, 1999) and to manipulate stock prices (ComertonForde and Rydge, 2006). The efficiency of the price discovery process at the opening might depend on whether participants may submit multiple orders and whether orders may be withdrawn before the opening (Chakraborty, Pagano and Schwartz, 2012). Similarly, pre-trade transparency may impact on market quality in a non-linear way (Eom, Ok and Park, 2007). There is also a possibility that auctions might not attract sufficient trading activity which may compromise their efficacy when order imbalances prevail (Madhavan and Panchapagesan, 2000).

This suggests that more research is required to investigate the interaction of call auctions with other market microstructure features and why their expected benefits 
This article is (c) Emerald Group Publishing and permission has been granted for this version to appear on www.um.edu.mt. Emerald does not grant permission for this article to be further copied/distributed or hosted elsewhere without the express permission from Emerald Group Publishing Limited.

Camilleri,S.J. (2015) "Do call auctions curtail price volatility? Evidence from the National Stock Exchange of India", Managerial Finance, 41 (1), pp. 67 - 79.

may not materialise. We believe that this constitutes an important aspect of future research. 
This article is (C) Emerald Group Publishing and permission has been granted for this version to appear on www.um.edu.mt. Emerald does not grant permission for this article to be further copied/distributed or hosted elsewhere without the express permission from Emerald Group Publishing Limited.

Camilleri,S.J. (2015) "Do call auctions curtail price volatility? Evidence from the National Stock Exchange of India", Managerial Finance, 41 (1), pp. 67 - 79.

\section{References}

Amihud, Y. and Mendelson, H. (1987), "Trading mechanisms and stock returns: an empirical investigation", Journal of Finance, Vol. 42 No. 3, pp. 533-53.

Andersen, T.G. and Bollerslev, T. (1997), "Intraday periodicity and volatility persistence in financial markets", Journal of Empirical Finance, Vol. 4 No. 2, pp. 115-58.

Biais, B., Hillion, P. and Spatt, C. (1999), "Price discovery and learning during the preopening period in the Paris bourse", Journal of Political Economy, Vol. 107 No. 6, pp. 1218-48.

Biais, B. and Pouget, S. (2000), "Microstructure, incentives, and the discovery of equilibrium in experimental financial markets", IDEI Working Papers 103, Institut d'Économie Industrielle (IDEI), Toulouse.

Caillaud, B. and Mezzetti, C. (2004), "Equilibrium reserve prices in sequential ascending auctions", Journal Of Economic Theory, Vol. 117 No. 1, pp. 78-95.

Camilleri, S.J. and Green, C.J. (2009), "The impact of the suspension of opening and closing call auctions: evidence from the national stock exchange of India", International Journal of Banking, Accounting and Finance, Vol. 1 No. 3, pp. 25784.

Camilleri, S.J. and Green, C.J. (2014), "Stock market predictability: non-synchronous trading or inefficient markets? evidence from the national stock exchange of India", Studies in Economics and Finance, forthcoming.

Chakraborty, A., Pagano, M.S. and Schwartz, R.A. (2012), "Order revelation at market openings", Journal of Financial Markets, Vol. 15 No. 2, pp. 127-50.

Chang, R.P., Ghon Ree, S., Stone, G.R. and Tang, N. (2008), "How does the call market method affect price efficiency? evidence from the Singapore stock market", Journal of Banking \& Finance, Vol. 32 No. 10, pp. 2205-19.

Chelley-Steeley, P.L. (2008), "Market quality changes in the London stock market", Journal of Banking \& Finance, Vol. 32 No. 10, pp. 2248-53.

Comerton-Forde, C. and Rydge, J. (2006), "Call auction algorithm design and market manipulation”, Journal of Multinational Financial Management, Vol. 16 No. 2, pp. 184-98. 
This article is (C) Emerald Group Publishing and permission has been granted for this version to appear on www.um.edu.mt. Emerald does not grant permission for this article to be further copied/distributed or hosted elsewhere without the express permission from Emerald Group Publishing Limited.

Camilleri,S.J. (2015) "Do call auctions curtail price volatility? Evidence from the National Stock Exchange of India", Managerial Finance, 41 (1), pp. 67 - 79.

Dacorogna, M., Gençay, R., Müller, U., Olsen, R. and Pictet, O. (2001), An introduction to high-frequency finance, Academic Press, San Diego CA.

Davies, R.J. (2003), "The Toronto stock exchange preopening session", Journal of Financial Markets, Vol. 6 No. 4, pp. 491-516.

Dia, M. and Pouget, S. (2011), "Sunshine trading in an African stock market", Managerial Finance, Vol. 37 No. 3, pp. 257-74.

Economides, N. and Schwartz, R.A. (1995), "Electronic call market trading", Journal of Portfolio Management, Vol. 21 No. 3, pp. 10-8.

Engle, R.F. (1982), "Autoregressive conditional heteroscedasticity with estimates of the variance of U.K. inflation”, Econometrica, Vol. 50 No. 4, pp. 987-1008.

Engle, R.F. (2001), "GARCH 101: The use of ARCH/GARCH models in applied econometrics", Journal of Economic Perspectives, Vol. 15 No. 4, pp. 157-68.

Engle, R.F. and Ng, V.K. (1993), "Measuring and testing the impact of news on volatility", The Journal of Finance, Vol. 48 No. 5, pp. 1749-78.

Eom, K.S., Ok, J. and Park, J.H. (2007), "Pre-trade transparency and market quality", Journal of Financial Markets, Vol. 10 No. 4, pp. 319-41.

Fama, E.F. (1970) "Efficient capital markets: a review of theory and empirical work", Journal of Finance, Vol. 25 No. 2, pp.383-417.

Franses, P.H. and van Dijk, D. (2000), Non-linear time series models in empirical finance, Cambridge University Press, Cambridge and New York.

Frino, A., Gerace, D. and Lepone, A. (2008), "Liquidity in auction and specialist market structures: evidence from the Italian bourse", Journal of Banking and Finance, Vol. 32 No. 12, pp. 2581-8.

Hillion, P. and Suominen, M. (2004), "The manipulation of closing prices", Journal of Financial Markets, Vol. 7 No. 4, pp. 351-75.

Klößner, S., Becker, M. and Friedmann, R. (2012), "Modeling and measuring intraday overreaction of stock prices", Journal of Banking \& Finance, Vol. 36 No. 4, pp. 1152-63.

Madhavan, A. (1992), "Trading mechanisms in securities markets", Journal of Finance, Vol. 47 No. 2, pp. 607-41. 
This article is (C) Emerald Group Publishing and permission has been granted for this version to appear on www.um.edu.mt. Emerald does not grant permission for this article to be further copied/distributed or hosted elsewhere without the express permission from Emerald Group Publishing Limited.

Camilleri,S.J. (2015) "Do call auctions curtail price volatility? Evidence from the National Stock Exchange of India", Managerial Finance, 41 (1), pp. 67 - 79.

Madhavan, A. and Panchapagesan, V. (2000), "Price discovery in auction markets: a look inside the black box", The Review of Financial Studies, Vol. 13 No. 3, pp. 627-58.

Madhavan, A., Richardson, M. and Roomans, M. (1997), "Why do security prices change? a transaction-level analysis of NYSE stocks", The Review of Financial Studies, Vol. 10 No. 4, pp. 1035-64.

Pinfold, J.F. and He, D. (2012), "The impact of introducing a pre-close on the New Zealand share market", Journal of Financial Regulation and Compliance, Vol. 20 No. 1, pp. 99-110.

Ronen, T. (1998), "Trading structure and overnight information: a natural experiment from the Tel-Aviv stock exchange", Journal of Banking and Finance, Vol. 22 No. 5, pp. 489-512.

Schwartz, R.A. (2000), "Building a better stock market: new solutions to old problems", Working Paper, AEI-Brookings Joint Center For Regulatory Studies.

Shastri, K.A., Shastri, K. and Sirodom, K. (1995), "Trading mechanisms and return volatility: an empirical analysis of the stock exchange of Thailand", Pacific-Basin Finance Journal, Vol. 3 No. 2-3, pp. 357-70.

Zhang, J., and Hu, W. (2013), "Does realised volatility provide additional information?", International Journal of Managerial Finance, Vol. 9 No. 1, pp. 7087. 
This article is (C) Emerald Group Publishing and permission has been granted for this version to appear on www.um.edu.mt. Emerald does not grant permission for this article to be further copied/distributed or hosted elsewhere without the express permission from Emerald Group Publishing Limited.

Camilleri,S.J. (2015) "Do call auctions curtail price volatility? Evidence from the National Stock Exchange of India", Managerial Finance, 41 (1), pp. 67 - 79.

\section{Tables:}

\begin{tabular}{|c|c|c|c|c|c|c|c|}
\hline Day & $\begin{array}{c}\text { AR } \\
\text { Intercept } \\
\hat{\varphi}\end{array}$ & $\begin{array}{c}\text { AR Lag } \\
\hat{\rho}\end{array}$ & $\mathrm{R}^{2}$ & Coeff: $\hat{\omega}$ & Coeff: $\hat{\alpha}$ & Coeff: $\hat{\beta}$ & Wald \\
\hline $\begin{array}{c}\text { A } 1 \\
t\end{array}$ & $\begin{array}{c}-0.000008 \\
(0.25) \\
\end{array}$ & $\begin{array}{c}0.4095 * * * \\
(7.75)\end{array}$ & 0.1613 & $\begin{array}{l}2.8 \mathrm{E}-07 \\
(0.0688)\end{array}$ & $\begin{array}{c}0.1226 \\
(1.25) \\
\end{array}$ & $\begin{array}{c}0.1992 \text { * } \\
(1.84)\end{array}$ & $\begin{array}{c}14.8 \\
\{65.9\}\end{array}$ \\
\hline $\begin{array}{c}\text { A } 2 \\
n\end{array}$ & $\begin{array}{c}0.000018 \\
(0.58)\end{array}$ & $\begin{array}{c}0.2757^{* * *} \\
(5.47)\end{array}$ & 0.1102 & $\begin{array}{c}9.1 \mathrm{E}-09 \\
(0.0021)\end{array}$ & $\begin{array}{c}0.0185 \\
(1.34)\end{array}$ & $\begin{array}{c}0.9506^{* * *} \\
(63.33)\end{array}$ & $\begin{array}{c}63509.7 \\
\{62.3\}\end{array}$ \\
\hline $\begin{array}{c}\text { A } 3 \\
t\end{array}$ & $\begin{array}{c}-0.000027 \\
(0.80)\end{array}$ & $\begin{array}{c}0.4386 \text { *** } \\
(8.90)\end{array}$ & 0.1916 & $\begin{array}{l}2.2 \mathrm{E}-08 \\
(0.0044) \\
\end{array}$ & $\begin{array}{c}0.0457 \\
(1.31) \\
\end{array}$ & $\begin{array}{c}0.8967^{* * *} \\
(26.17) \\
\end{array}$ & $\begin{array}{c}10545.7 \\
\{38.0\}\end{array}$ \\
\hline $\begin{array}{c}\text { A } 4 \\
n\end{array}$ & $\begin{array}{c}0.000022 \\
(0.67)\end{array}$ & $\begin{array}{c}0.3881^{* * *} \\
(7.65)\end{array}$ & 0.1121 & $\begin{array}{c}3.6 \mathrm{E}-08 \\
(0.0091)\end{array}$ & $\begin{array}{c}0.0346 \\
(1.51)\end{array}$ & $\begin{array}{c}0.8593^{* * *} \\
(34.82)\end{array}$ & $\begin{array}{c}6574.7 \\
\{92.4\}\end{array}$ \\
\hline $\begin{array}{c}\text { A } 5 \\
n\end{array}$ & $\begin{array}{c}0.000026 \\
(1.04)\end{array}$ & $\begin{array}{c}0.2838 \text { *** } \\
(5.45)\end{array}$ & 0.0925 & $\begin{array}{c}1.2 \mathrm{E}-08 \\
(0.0030)\end{array}$ & $\begin{array}{c}0.0626 \text { ** } \\
(2.36)\end{array}$ & $\begin{array}{c}0.8780 \text { *** } \\
(32.67)\end{array}$ & $\begin{array}{c}9889.6 \\
\{38.8\}\end{array}$ \\
\hline $\begin{array}{c}\text { A } 6 \\
n\end{array}$ & $\begin{array}{c}-0.000027 \\
(0.70)\end{array}$ & $\begin{array}{c}0.3747^{* * *} \\
(6.56)\end{array}$ & 0.1680 & $\begin{array}{l}3.6 \mathrm{E}-08 \\
(0.0081)\end{array}$ & $\begin{array}{c}0.1505^{* * *} \\
(2.71)\end{array}$ & $\begin{array}{c}0.7985 \text { *** } \\
(17.25)\end{array}$ & $\begin{array}{c}3962.3 \\
\{7.4\}\end{array}$ \\
\hline $\begin{array}{c}\text { A } 8 \\
n\end{array}$ & $\begin{array}{c}-0.000038 \\
(0.82)\end{array}$ & $\begin{array}{c}0.4000^{* * *} \\
(7.83)\end{array}$ & 0.1129 & $\begin{array}{c}3.9 E-08 \\
(0.0087)\end{array}$ & $\begin{array}{c}0.0835^{* *} \\
(2.29)\end{array}$ & $\begin{array}{c}0.8655^{* * *} \\
(25.90)\end{array}$ & $\begin{array}{c}8665.2 \\
\{21.2\}\end{array}$ \\
\hline $\begin{array}{c}\text { A } 9 \\
n\end{array}$ & $\begin{array}{c}0.000043 \\
(1.59)\end{array}$ & $\begin{array}{c}0.3750 \text { *** } \\
(7.11)\end{array}$ & 0.1789 & $\begin{array}{l}4.1 \mathrm{E}-08 \\
(0.0105)\end{array}$ & $\begin{array}{c}0.2257^{* * *} \\
(3.37)\end{array}$ & $\begin{array}{c}0.6496 \text { *** } \\
(12.06)\end{array}$ & $\begin{array}{l}1211.5 \\
\{17.4\}\end{array}$ \\
\hline $\begin{array}{c}A 10 \\
t\end{array}$ & $\begin{array}{c}0.000021 \\
(0.65)\end{array}$ & $\begin{array}{c}0.3500^{* * *} \\
(6.67)\end{array}$ & 0.1327 & $\begin{array}{c}1.4 \mathrm{E}-08 \\
(0.0028)\end{array}$ & $\begin{array}{c}0.0939 \text { ** } \\
(2.21)\end{array}$ & $\begin{array}{c}0.8756 \text { *** } \\
(24.75)\end{array}$ & $\begin{array}{c}7225.3 \\
\{4.5\}\end{array}$ \\
\hline $\begin{array}{c}\text { A } 11 \\
n\end{array}$ & $\begin{array}{c}0.000010 \\
(0.44)\end{array}$ & $\begin{array}{c}0.3923 * * * \\
(7.74)\end{array}$ & 0.1339 & $\begin{array}{l}6.1 \mathrm{E}-09 \\
(0.0015) \\
\end{array}$ & $\begin{array}{c}0.0344 \text { * } \\
(1.70) \\
\end{array}$ & $\begin{array}{c}0.9260 * * * \\
(44.94)\end{array}$ & $\begin{array}{c}28603.8 \\
\{48.3\} \\
\end{array}$ \\
\hline $\begin{array}{c}A 13 \\
t\end{array}$ & $\begin{array}{c}-0.000001 \\
(0.05)\end{array}$ & $\begin{array}{c}0.2195^{* * *} \\
(4.34)\end{array}$ & 0.1927 & $\begin{array}{c}9.8 E-09 \\
(0.0023)\end{array}$ & $\begin{array}{c}0.0773^{* *} \\
(2.15)\end{array}$ & $\begin{array}{c}0.8578^{* * *} \\
(26.05)\end{array}$ & $\begin{array}{c}5168.3 \\
\{21.4\}\end{array}$ \\
\hline $\begin{array}{c}\text { A } 14 \\
t\end{array}$ & $\begin{array}{c}-0.000009 \\
(0.38)\end{array}$ & $\begin{array}{c}0.3283^{* * *} \\
(6.24)\end{array}$ & 0.0840 & $\begin{array}{l}2.5 \mathrm{E}-08 \\
(0.0054)\end{array}$ & $\begin{array}{c}0.0664 \\
(1.37) \\
\end{array}$ & $\begin{array}{c}0.8334^{* * *} \\
(20.17)\end{array}$ & $\begin{array}{c}1902.2 \\
\{17.8\}\end{array}$ \\
\hline $\begin{array}{c}\text { A } 15 \\
n\end{array}$ & $\begin{array}{c}0.000028 \\
(1.23)\end{array}$ & $\begin{array}{c}0.4129 * * * \\
(8.74)\end{array}$ & 0.2092 & $\begin{array}{c}7.7 E-08 \\
(0.0209)\end{array}$ & $\begin{array}{c}0.2977^{* * *} \\
(3.49)\end{array}$ & $\begin{array}{c}0.3661^{* * *} \\
(5.43)\end{array}$ & $\begin{array}{l}154.4 \\
\{34.1\}\end{array}$ \\
\hline
\end{tabular}

The first column shows the trading day in the auction period $(A)$ or the suspension period $(S)$, whilst the letter " $t$ " or " $n$ " indicates whether the conditional distribution for the error terms was assumed to be normal $(n)$ or student-t $(t)$. Log returns were modelled as an $A R(1)$ process, where $\varphi$ refers to the intercept and $\rho$ is the estimated coefficient of the lagged return. T-ratios are shown in brackets underneath the coefficients and significance at the $99 \%, 95 \%$ and $90 \%$ confidence levels is denoted by ${ }^{* * *},{ }^{* *}$ and * respectively. $\mathrm{R}^{2}$ shows the explanatory power of the regression. The coefficients of the GARCH process are $\omega$ (the intercept), $\alpha$ (lagged error term) and $\beta$ (lagged conditional variance). The final column shows the results for the Wald Tests on the GARCH process. The null hypothesis of the first test is that $\alpha=0$ and $\beta=0$. The test is $\chi^{2}(2)$ distributed with a $95 \%$ critical value of 5.991 . The result for the second Wald test is shown in braces underneath. The null hypothesis is that $\alpha+\beta=1$ and the test is $x^{2}(1)$ distributed with a $95 \%$ critical value of 3.841 . When the null hypothesis was not rejected, the particular model was discarded (therefore not reported in the table). 
This article is (c) Emerald Group Publishing and permission has been granted for this version to appear on www.um.edu.mt. Emerald does not grant permission for this article to be further copied/distributed or hosted elsewhere without the express permission from Emerald Group Publishing Limited.

Camilleri,S.J. (2015) "Do call auctions curtail price volatility? Evidence from the National Stock Exchange of India", Managerial Finance, 41 (1), pp. 67 - 79.

\begin{tabular}{|c|c|c|c|c|c|c|c|}
\hline Day & $\begin{array}{c}\text { AR } \\
\text { Intercept } \\
\hat{\varphi}\end{array}$ & $\begin{array}{c}\text { AR Lag } \\
\hat{\rho}\end{array}$ & $\mathrm{R}^{2}$ & Coeff: $\hat{\omega}$ & Coeff: $\hat{\alpha}$ & Coeff: $\hat{\beta}$ & Wald \\
\hline $\begin{array}{c}\mathrm{S} 2 \\
\mathrm{n}\end{array}$ & $\begin{array}{c}-0.000016 \\
(0.76)\end{array}$ & $\begin{array}{c}0.2634^{* * *} \\
(5.20)\end{array}$ & 0.1563 & $\begin{array}{l}3.2 \mathrm{E}-09 \\
(0.0008)\end{array}$ & $\begin{array}{c}0.0426 \text { ** } \\
(2.04)\end{array}$ & $\begin{array}{c}0.9358^{* * *} \\
(47.82)\end{array}$ & $\begin{array}{c}37260.4 \\
\{16.0\}\end{array}$ \\
\hline $\begin{array}{c}\text { S 3 } \\
t\end{array}$ & $\begin{array}{c}-0.000018 \\
(0.79)\end{array}$ & $\begin{array}{c}0.3003^{* * *} \\
(5.59)\end{array}$ & 0.0771 & $\begin{array}{l}2.1 \mathrm{E}-09 \\
(0.0004)\end{array}$ & $\begin{array}{c}0.0420 \\
(1.61) \\
\end{array}$ & $\begin{array}{c}0.9448 \text { *** } \\
(40.67)\end{array}$ & $\begin{array}{c}39661.2 \\
\{4.8\}\end{array}$ \\
\hline $\begin{array}{c}\mathrm{S} 4 \\
\mathrm{n}\end{array}$ & $\begin{array}{c}0.000034 \\
(1.56)\end{array}$ & $\begin{array}{c}0.3343^{* * *} \\
(7.63)\end{array}$ & 0.5643 & $\begin{array}{l}8.7 \mathrm{E}-09 \\
(0.0022)\end{array}$ & $\begin{array}{c}0.0475^{* *} \\
(2.18)\end{array}$ & $\begin{array}{c}0.8857^{* * *} \\
(38.45)\end{array}$ & $\begin{array}{c}12464.2 \\
\{63.9\}\end{array}$ \\
\hline $\begin{array}{c}S 7 \\
t\end{array}$ & $\begin{array}{c}0.000019 \\
(0.65)\end{array}$ & $\begin{array}{c}0.3382^{* * *} \\
(6.45)\end{array}$ & 0.0728 & $\begin{array}{l}2.4 \mathrm{E}-08 \\
(0.0046) \\
\end{array}$ & $\begin{array}{l}0.0618 \\
(1.11) \\
\end{array}$ & $\begin{array}{c}0.8567^{* * *} \\
(15.96)\end{array}$ & $\begin{array}{c}4496.6 \\
\{33.4\}\end{array}$ \\
\hline $\begin{array}{c}S 9 \\
t\end{array}$ & $\begin{array}{c}0.000032 \\
(1.53)\end{array}$ & $\begin{array}{c}0.2957^{* * *} \\
(5.52)\end{array}$ & 0.1558 & $\begin{array}{l}1.2 \mathrm{E}-08 \\
(0.0024)\end{array}$ & $\begin{array}{l}0.0448 \\
(0.88)\end{array}$ & $\begin{array}{c}0.8647^{* * *} \\
(16.89)\end{array}$ & $\begin{array}{c}5377.8 \\
\{53.0\}\end{array}$ \\
\hline $\begin{array}{c}S 11 \\
t\end{array}$ & $\begin{array}{c}-0.000040 \\
(1.46) \\
\end{array}$ & $\begin{array}{c}0.3704^{* * *} \\
(7.41)\end{array}$ & 0.1453 & $\begin{array}{l}1.1 \mathrm{E}-08 \\
(0.0023) \\
\end{array}$ & $\begin{array}{l}0.0227 \\
(1.18)\end{array}$ & $\begin{array}{c}0.9370^{* * *} \\
(49.33)\end{array}$ & $\begin{array}{c}15808.4 \\
\{26.5\}\end{array}$ \\
\hline $\begin{array}{c}\mathrm{S} 12 \\
\mathrm{n}\end{array}$ & $\begin{array}{c}-0.000007 \\
(0.26)\end{array}$ & $\begin{array}{c}0.3961^{* * *} \\
(7.50)\end{array}$ & 0.1859 & $\begin{array}{l}4.6 \mathrm{E}-08 \\
(0.0117) \\
\end{array}$ & $\begin{array}{c}0.0732 \text { * } \\
(1.84)\end{array}$ & $\begin{array}{c}0.7430^{* * *} \\
(17.67)\end{array}$ & $\begin{array}{l}1625.9 \\
\{81.7\}\end{array}$ \\
\hline $\begin{array}{c}\mathrm{S} 13 \\
\mathrm{n}\end{array}$ & $\begin{array}{c}-0.000008 \\
(0.34)\end{array}$ & $\begin{array}{c}0.3721^{* * *} \\
(7.14)\end{array}$ & 0.1356 & $\begin{array}{l}9.7 \mathrm{E}-09 \\
(0.0020)\end{array}$ & $\begin{array}{l}0.0372 \\
(0.95)\end{array}$ & $\begin{array}{c}0.9017^{* * *} \\
(23.56)\end{array}$ & $\begin{array}{c}14297.6 \\
\{57.9\}\end{array}$ \\
\hline $\begin{array}{c}S 14 \\
t\end{array}$ & $\begin{array}{c}-0.000015 \\
(0.82)\end{array}$ & $\begin{array}{c}0.2332 * * * \\
(3.90)\end{array}$ & 0.0203 & $\begin{array}{l}3.6 \mathrm{E}-08 \\
(0.0093)\end{array}$ & $\begin{array}{c}0.1548 \text { ** } \\
(2.17)\end{array}$ & $\begin{array}{c}0.5373^{* * *} \\
(7.71)\end{array}$ & $\begin{array}{l}156.2 \\
\{28.7\}\end{array}$ \\
\hline $\begin{array}{c}S 15 \\
t\end{array}$ & $\begin{array}{c}-0.000007 \\
(0.39)\end{array}$ & $\begin{array}{c}0.3129 * * * \\
(5.75)\end{array}$ & 0.0845 & $\begin{array}{l}2.1 \mathrm{E}-08 \\
(0.0050)\end{array}$ & $\begin{array}{l}0.0579 \\
(0.96)\end{array}$ & $\begin{array}{c}0.7502^{* * *} \\
(12.67) \\
\end{array}$ & $\begin{array}{l}688.5 \\
\{36.2\}\end{array}$ \\
\hline
\end{tabular}


This article is (c) Emerald Group Publishing and permission has been granted for this version to appear on www.um.edu.mt. Emerald does not grant permission for this article to be further copied/distributed or hosted elsewhere without the express permission from Emerald Group Publishing Limited.

Camilleri,S.J. (2015) "Do call auctions curtail price volatility? Evidence from the National Stock Exchange of India", Managerial Finance, 41 (1), pp. 67 - 79.

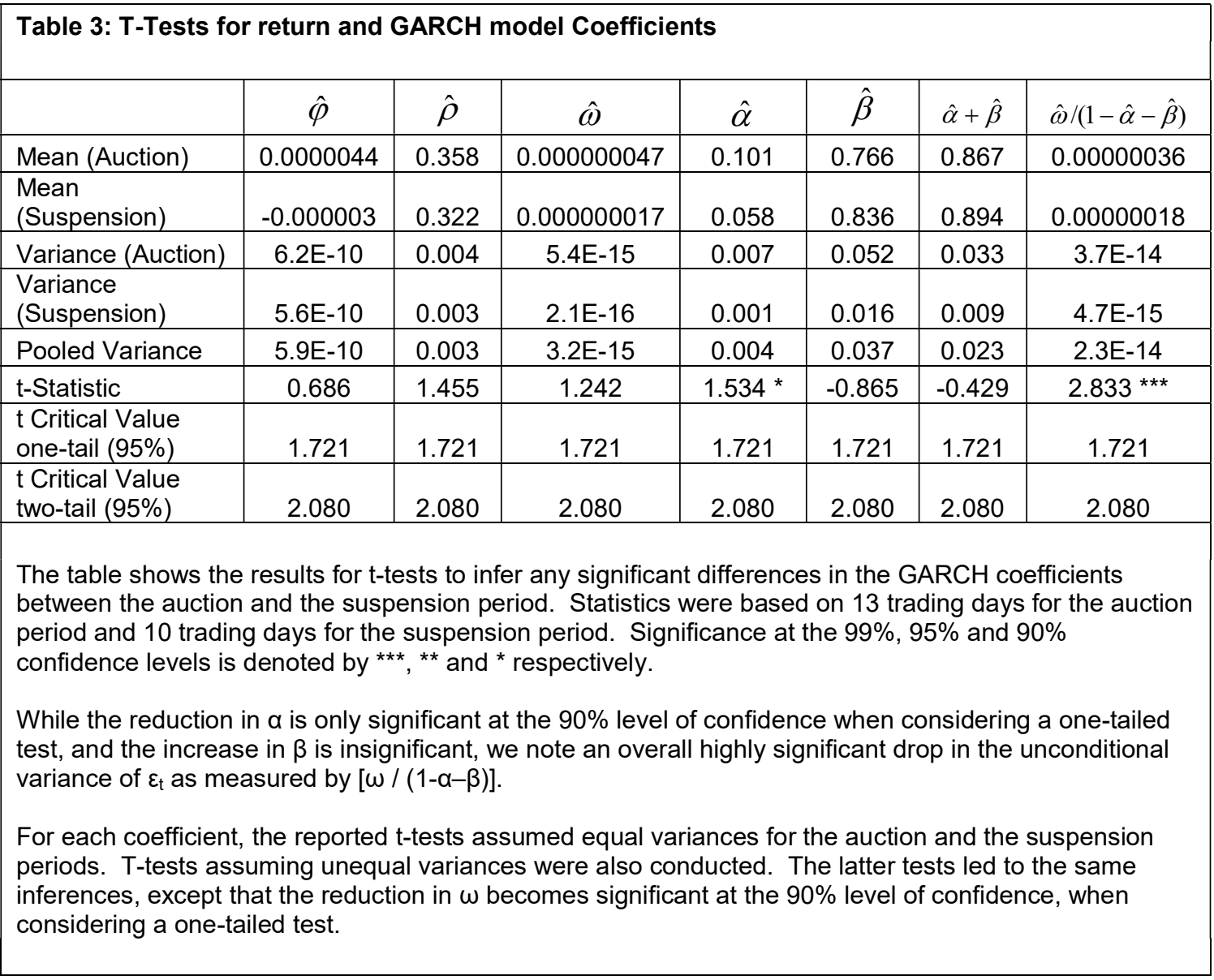


This article is (c) Emerald Group Publishing and permission has been granted for this version to appear on www.um.edu.mt. Emerald does not grant permission for this article to be further copied/distributed or hosted elsewhere without the express permission from Emerald Group Publishing Limited.

Camilleri,S.J. (2015) "Do call auctions curtail price volatility? Evidence from the National Stock Exchange of India", Managerial Finance, 41 (1), pp. 67 - 79.

Table 4: T-tests on differences in volatility during the trading day

PANEL A: Two-tailed paired sample t-tests tests on mean squared returns of the 30 sampled trading days

\begin{tabular}{|l|c|c|c|}
\hline Null Hypothesis & $\begin{array}{c}\text { Outcome } \\
\text { - Confidence Level }\end{array}$ & T-Statistic & $\begin{array}{c}\text { Critical } \\
\text { Value }\end{array}$ \\
\hline No Diff. Between Open. \& Mid. & Rejected - 95\% & 3.6 & 2.0 \\
No Diff. Between Open. \& Clos. & Rejected - 95\% & 2.8 & 2.0 \\
No Diff. Between Mid. \& Clos. & Rejected - 95\% & 2.2 & 2.0 \\
\hline
\end{tabular}

PANEL B: Two-tailed paired sample t-tests tests on return std. deviations of the 30 sampled trading days

\begin{tabular}{|l|c|c|c|}
\hline Null Hypothesis & $\begin{array}{c}\text { Outcome } \\
\text { - Confidence Level }\end{array}$ & T-Statistic & $\begin{array}{c}\text { Critical } \\
\text { Value }\end{array}$ \\
\hline No Diff. Between Open. \& Mid. & Rejected - 95\% & 6.2 & 2.0 \\
No Diff. Between Open. \& Clos. & Rejected - 95\% & 4.4 & 2.0 \\
No Diff. Between Mid. \& Clos. & Rejected - 95\% & 3.6 & 2.0 \\
\hline
\end{tabular}

The table shows the outcomes of two-tailed paired sample t-tests on the differences in volatility during the opening, middle-of-the-day and closing periods. Panel A shows the outcomes of tests on Mean Squared Returns as a volatility proxy. Panel B shows the outcomes of tests on Return Standard Deviations as a volatility proxy. The null hypothesis of no difference between the respective volatility proxies during the different periods of the day is uniformly rejected at the $95 \%$ level of confidence. 
This article is (c) Emerald Group Publishing and permission has been granted for this version to appear on www.um.edu.mt. Emerald does not grant permission for this article to be further copied/distributed or hosted elsewhere without the express permission from Emerald Group Publishing Limited.

Camilleri,S.J. (2015) "Do call auctions curtail price volatility? Evidence from the National Stock Exchange of India", Managerial Finance, 41 (1), pp. 67 - 79.

\section{Table 5: Summary statistics for one-minute return distributions}

\begin{tabular}{|c|c|c|c|c|c|c|c|c|}
\hline & & \multicolumn{3}{|c|}{ LOG RETURNS } & \multicolumn{4}{|c|}{ SQUARED LOG RETURNS } \\
\hline & & St.Dev & Skew. & $\mathrm{K}-3$ & Mean & St.Dev & Max & Min \\
\hline Op. & Avg : 30 Days & 0.0012 & 0.835 & 6.710 & 0.00000193 & 0.0000068 & 0.0000403 & 0 \\
\hline Mid. & Avg : 30 Days & 0.0005 & -0.048 & 1.312 & 0.00000027 & 0.0000005 & 0.0000041 & 0 \\
\hline Cl. & Avg : 30 Days & 0.0007 & 0.155 & 0.428 & 0.00000055 & 0.0000009 & 0.0000041 & 0 \\
\hline Op. & Avg: A & 0.0012 & 0.339 & 4.313 & 0.00000164 & 0.0000047 & 0.0000278 & 0 \\
\hline Op. & Avg: $S$ & 0.0012 & 1.330 & 9.106 & 0.00000222 & 0.0000088 & 0.0000528 & 0 \\
\hline Mid. & Avg: A & 0.0006 & -0.131 & 1.740 & 0.00000034 & 0.0000006 & 0.0000054 & 0 \\
\hline Mid. & Avg: $S$ & 0.0004 & 0.035 & 0.884 & 0.00000020 & 0.0000003 & 0.0000028 & 0 \\
\hline Cl. & Avg: A & 0.0008 & 0.156 & 0.692 & 0.00000079 & 0.0000014 & 0.0000062 & 0 \\
\hline $\mathrm{Cl}$. & Avg: $S$ & 0.0005 & 0.153 & 0.165 & 0.00000031 & 0.0000004 & 0.0000020 & 0 \\
\hline
\end{tabular}

The table shows summary statistics for Intra-Day Return Distributions. The columns indicate the following: (1) Period of the Day (Opening / Middle / Closing); (2) Average for the particular period [30Day Sample / Auction Period (A) / Suspension Period (S)]; (3) Standard Deviation of Returns; (4) Skewness of Returns; (5) Excess Kurtosis of Returns; (6) Mean of Squared Returns; (7) Standard Deviation of Squared Returns; (8) Maximum Squared Return; and (9) Minimum Squared Return. 
This article is (c) Emerald Group Publishing and permission has been granted for this version to appear on www.um.edu.mt. Emerald does not grant permission for this article to be further copied/distributed or hosted elsewhere without the express permission from Emerald Group Publishing Limited.

Camilleri,S.J. (2015) "Do call auctions curtail price volatility? Evidence from the National Stock Exchange of India", Managerial Finance, 41 (1), pp. 67 - 79.

\begin{tabular}{|c|c|c|c|c|c|}
\hline Day & Op - 10:15 & $10: 15-12: 30$ & $10: 15-\mathrm{Cl}$ & RF / REV - 12:30 & RF / REV - Cl. \\
\hline A 1 & $0.56 \%$ & $1.44 \%$ & $0.16 \%$ & RF & RF \\
\hline A 2 & $1.30 \%$ & $0.61 \%$ & $0.45 \%$ & $\mathrm{RF}$ & $\mathrm{RF}$ \\
\hline A 3 & $0.85 \%$ & $-1.01 \%$ & $-1.90 \%$ & REV & REV \\
\hline A 4 & $-0.66 \%$ & $1.07 \%$ & $1.09 \%$ & REV & REV \\
\hline A 5 & $-0.13 \%$ & $0.62 \%$ & $0.89 \%$ & REV & REV \\
\hline A 6 & $0.61 \%$ & $-1.99 \%$ & $-2.72 \%$ & REV & REV \\
\hline A 7 & $-0.49 \%$ & $1.53 \%$ & $-3.41 \%$ & REV & $\mathrm{RF}$ \\
\hline A 8 & $0.09 \%$ & $-2.50 \%$ & $-1.01 \%$ & REV & REV \\
\hline A 9 & $3.53 \%$ & $-0.09 \%$ & $1.14 \%$ & REV & $\mathrm{RF}$ \\
\hline A 10 & $-1.01 \%$ & $1.47 \%$ & $0.29 \%$ & REV & REV \\
\hline A 11 & $-0.28 \%$ & $-0.90 \%$ & $0.41 \%$ & $\mathrm{RF}$ & REV \\
\hline A 12 & $0.73 \%$ & $-0.35 \%$ & $0.26 \%$ & REV & $\mathrm{RF}$ \\
\hline A 13 & $1.90 \%$ & $-0.40 \%$ & $-0.26 \%$ & REV & REV \\
\hline A 14 & $0.68 \%$ & $0.08 \%$ & $-0.51 \%$ & $\mathrm{RF}$ & REV \\
\hline A 15 & $-1.42 \%$ & $1.85 \%$ & $3.26 \%$ & REV & REV \\
\hline S 1 & $-0.05 \%$ & $0.01 \%$ & $-1.45 \%$ & REV & RF \\
\hline S 2 & $1.00 \%$ & $-0.21 \%$ & $-1.11 \%$ & REV & REV \\
\hline S 3 & $-0.08 \%$ & $-1.40 \%$ & $-1.67 \%$ & $\mathrm{RF}$ & $\mathrm{RF}$ \\
\hline S 4 & $-3.02 \%$ & $0.47 \%$ & $2.10 \%$ & REV & REV \\
\hline S 5 & $0.48 \%$ & $0.08 \%$ & $-1.44 \%$ & $\mathrm{RF}$ & REV \\
\hline S 6 & $-0.24 \%$ & $-0.41 \%$ & $2.80 \%$ & RF & REV \\
\hline S 7 & $0.95 \%$ & $1.09 \%$ & $1.48 \%$ & RF & $\mathrm{RF}$ \\
\hline S 8 & $0.27 \%$ & $0.08 \%$ & $-0.47 \%$ & RF & REV \\
\hline S 9 & $0.87 \%$ & $0.63 \%$ & $1.44 \%$ & RF & $\mathrm{RF}$ \\
\hline S 10 & $0.62 \%$ & $0.44 \%$ & $0.59 \%$ & $\mathrm{RF}$ & $\mathrm{RF}$ \\
\hline S 11 & $0.41 \%$ & $-1.79 \%$ & $-2.49 \%$ & REV & REV \\
\hline S 12 & $-0.48 \%$ & $-0.64 \%$ & $-0.58 \%$ & $\mathrm{RF}$ & $\mathrm{RF}$ \\
\hline S 13 & $0.53 \%$ & $0.42 \%$ & $-0.74 \%$ & $\mathrm{RF}$ & REV \\
\hline S 14 & $0.48 \%$ & $-0.73 \%$ & $-0.51 \%$ & REV & REV \\
\hline S 15 & $-0.19 \%$ & $-0.56 \%$ & $-0.31 \%$ & $\mathrm{RF}$ & $\mathrm{RF}$ \\
\hline \multicolumn{4}{|c|}{ 30-DAY SAMPLE: } & $\begin{array}{c}\text { REV: } 16 \\
\text { RF: } 14\end{array}$ & $\begin{array}{l}\text { REV: } 18 \\
\text { RF: } 12\end{array}$ \\
\hline \multicolumn{4}{|c|}{ AUCTION PERIOD: } & $\begin{array}{c}\text { REV: } 11 \\
\text { RF: } 4\end{array}$ & $\begin{array}{c}\text { REV: } 10 \\
\text { RF: } 5 \\
\end{array}$ \\
\hline \multicolumn{4}{|c|}{ SUSPENSION PERIOD: } & $\begin{array}{l}\text { REV: } 5 \\
\text { RF: } 10\end{array}$ & $\begin{array}{l}\text { REV: } 8 \\
\text { RF: } 7\end{array}$ \\
\hline \multicolumn{6}{|c|}{$\begin{array}{l}\text { The table shows intra-day returns for the } 15 \text { trading days in the auction period }(\mathrm{A}) \text { and the } 15 \\
\text { trading days in the suspension period (S). The returns columns show the } \% \text { changes in the } \\
\text { index level from the opening to } 10: 15 \text {, from } 10: 15 \text { till } 12: 30 \text {, and from } 10: 15 \text { till the end of the } \\
\text { day. When the direction of the opening return is the same as that of the subsequent return, } \\
\text { the sequence is classified as a reinforcement (RF). When the opening return changes } \\
\text { direction during the rest of the day, the sequence is classified as a reversal (RV). }\end{array}$} \\
\hline
\end{tabular}


This article is (c) Emerald Group Publishing and permission has been granted for this version to appear on www.um.edu.mt. Emerald does not grant permission for this article to be further copied/distributed or hosted elsewhere without the express permission from Emerald Group Publishing Limited.

Camilleri,S.J. (2015) "Do call auctions curtail price volatility? Evidence from the National Stock Exchange of India", Managerial Finance, 41 (1), pp. 67 - 79.

\section{Footnotes}

1 We used the asymmetric volatility test of Engle and $\mathrm{Ng}(1993)$ where the squared error term from an $A R(1)$ model is regressed over a constant, an error term and a dummy variable of the lagged error sign which denotes asymmetric volatility. The latter was only significant in four trading days out of fifteen.

2 Dummy variables were also included in GARCH models to account for higher volatility at the opening and at the close, yet these estimations tended not to converge.

3 We inquired whether there was a tendency for overreactions (reversals) to coincide with bad news (negative initial returns), in line with Klößner, Becker and Friedmann (2012). Whilst initial negative returns were reversed / partially reversed by the end of the day in $58 \%$ of the cases, initial positive returns were reversed / partially reversed in $61 \%$ of the cases, suggesting that reversals in our sample are not associated with bad news. 